\title{
Mixed reactions to merger
}

\section{Washington}

THREE weeks after Genentech Inc. announced its 'marriage' to the Swissbased company, Roche Holdings Ltd, biotechnology executives and stock analysts have mixed opinions, but no one is predicting a wave of merger mania among biotechnology companies. The Genentech deal gives Roche a 60 per cent stake in the South San Francisco-based company in return for a $\$ 2,100$ million investment (see Nature 343, 495; 8 February 1990), providing Genentech with the capital to pursue an ambitious drug development programme free from Wall Street's pressure on quarterly earnings.

Many people expected Genentech, the first biotechnology company to go public (in October 1980), to become the next major independent drug-producing company in the United States, but the Roche deal has emphasized the capital-intensive nature of the industry. It can take 7-10 years and an investment of \$125-\$150 million to bring a drug to market. Lowell Sears, chief financial officer at Amgen, points out that there is a "lack of appetite for investment [by US financial markets] in the future of biotechnology" and that "the management at Genentech had grown weary of the scepticism and lack of commitment from financial markets". "Equity investors still consider biotechnology to be a risky business", says Pamela J. Bridgen, executive director of the Association of Biotechnology Companies. Consequently, Genentech stock was probably undervalued.

The Genentech-Roche merger provides, says Katharine Russell of Cetus Corporation, an "outside-the-industry validation" of biotechnology. Clearly, Roche has put a value on the two Genentech products already on the market - the blood clot-dissolving drug Activase (tissue plasminogen activator, TPA) and Protropin (human growth hormone), and on its valuable longer-term pipeline of products. John Girton, a San Francisco stock analyst, says the share prices for Amgen, Inc., Chiron Corporation and Cetus Corporation rallied after the 2 February announcement. The news, he says, has introduced a "take-over premium" into other companies.

Indeed, four days after the Genentech announcement, Cetus went back to the equity markets for an injection of capital. It made a secondary issue of 2.6 million common shares - money that Cetus says is earmarked for financing clinical testing and improving its sales and marketing infrastructure. But Denise Gilbert, a San Francisco analyst, warned that this optimism may be premature. This is a "one-of-a-kind deal" because "Genentech has assets that no other company has".
Genentech has fewer strategic alliances with other companies and has retained the marketing rights to its own products. Gilbert believes that the deal will make Genentech more formidable and, consequently, the rest of the industry must look over its shoulder to see what Genentech will do. One possibility is that Genentech may try to obtain the marketing rights to other company's products.

But Girton disagrees, saying that although Genentech was particularly attractive, it was not unique. He cites Amgen, Cetus, Immunex, Genetics Institute and Biogen as also having valuable long-term product pipelines.

Richard D. Godown, president of the Industrial Biotechnology Association, observes that in 15 years of biotechnology, the Genentech-Roche deal is only the third major acquisition of a biotechnology company. A wave of buyouts was predicted in 1986 when Eli Lilly \& Company bought Hybritech and the Bristol-Myers Company acquired Genetic Systems Corporation, but did not materialize. Godown points out that Genentech was not forced into the merger and that discussions were initiated by the company. It was not because of "pressing economic necessity, but as a matter of corporate planning", says Godown.

This sentiment is echoed by Girton, who says that Genentech was "funding about $\$ 145$ million of R\&D a year and was profitable to the tune of $\$ 40$ million a year". He believes that the venture capitalists "cashed out" and put a "ceiling limit" on the share price. No one is going to pay more than $\$ 38$ per share this year, knowing that Roche can exercise its right to buy outstanding shares at that price.

The latest deal gives Roche access to the two most promising areas of biotechnology. It already owns a 4.5 per cent stake in Cetus, and its wholly owned US subsidiary Hoffman-La Roche of Nutley, New Jersey, is licensed to develop diagnostic products using Cetus's PCR (polymerase chain reaction) technology. Whether Genentech can maintain an arms-length relationship with Roche remains to be seen. Girton sees Genentech becoming a division of Hoffman-La Roche, and Godown says it is "reasonable to assume the inevitable coming together of Hoffman-La Roche and Genentech".

There has been little political comment over the fact that a controlling interest in the leading US biotechnology company is in foreign hands. Representatives Rick Boucher (Democrat, Virginia) and Carlos Moorhead (Republican, California), recognizing that too many home-grown industries are being swallowed up by foreign competitors, have introduced a bill to stop unfair foreign competition in

\section{Biologist Phillip A. Sharp chosen} Boston

Phillip A. Sharp, a well-known cancer biologist, has been selected as the new president of the Massachusetts Institute of Technology (MIT). Although the decision will not be confirmed officially until a vote by the MIT Corporation on 2 March, the choice has already been approved by MIT's search committee and faculty advisory committees.

\section{IMAGE UNAVAILABLE FOR COPYRIGHT REASONS}

Professor Phillip A. Sharp - new MIT president.

Sharp, 46, is currently director of MIT's Center for Cancer Research and will be the first biologist ever to head the university, a sign of the increasing prominence of biological research at the institute. $\mathrm{He}$ is known for the discovery in 1977 of surplus DNA and the splicing of RNA, and was a 1988 Lasker award-winner. $\mathrm{He}$ is also a cofounder and board member of the biotechnology company Biogen, an affiliation that is said to have earned him millions of dollars' worth of stock.

Sharp's selection caused some surprise at the university: he is a scientist, not an engineer, and works in the life sciences rather than the physical sciences. $\mathrm{He}$ is a well-known researcher but has had little involvement in the university's administration. Some members of the selection committee said that they hoped these attributes would allow Sharp a "fresh opportunity" to examine the school and to exert an influential voice on behalf of the scientific community. Sharp has declined to speak publicly about his new post until he is officially confirmed.

Two prominent early candidates for the presidency of MIT dropped out of the competition. David Baltimore, one of Sharp's closest colleagues, recently accepted the presidency of Rockefeller University in New York, and MIT Provost John Deutch withdrew his name earlier this month, after controversy about his corporate and military ties (see Nature 343, 585; 15 February 1990). Seth Shulman

biotechnology. The bill seeks to eliminate certain unfair advantages that US patent law now confers on foreign competitors. But asked about the Genentech-Roche deal, Boucher said only that he regretted both that it had happened and that it had become necessary.

Dlane Gershon 